\title{
LA FAMILIA, LA ESCUELA Y LA \\ AUTORIDAD
}

Émile Durkheim y Paul Desjardins

DESJARDINS: (..) Pero una de las causas que hacen necesaria la creación de escuelas nuevas, es la incapacidad de la familia francesa actual de educar a sus hijos.

DURKHEIM: ¿No habrá exageración al hablar así de la familia de hoy en día? Estoy de acuerdo, y soy el primero en deplorar, que la noción de autoridad ha decaído en la familia y en la escuela. Pero no debemos olvidar que en nuestros años era ruda en exceso. Nuestros inmediatos predecesores lucharon por suavizarla. Convengo en que ellos sobrepasaron la medida, pero no hay que olvidar lo que hicieron y lo que les debemos. En suma, ello no demuestra que la familia esté sensiblemente por debajo de lo que ella ha sido: es sólo diferente.

\footnotetext{
Publicado originalmente en Libres entretiens de la Union por la Vérité, octava serie, Paris, 1912, p.322.
} 